\title{
Margaret McCartney: One of the best-a GP who campaigned against corporal punishment
}

\author{
Margaret McCartney general practitioner, Glasgow
}

My father in law, Cyril Daly, has died.

He was a general practitioner in the north of Dublin. He was truly singlehanded-just him, no nurse, no secretary, no receptionist. Patients wanting to be seen simply turned up and waited during specified hours.

The surgery, appended to the side of the house, had a waiting room with comfortable chairs and paintings to admire. No health promotion leaflets or posters cluttered the walls. Cyril didn't use a computer. He wrote records on cards and stored them in drawers organised alphabetically.

In Ireland, GPs older than 75 are not allowed to continue looking after "medical card" (state paid) patients; Cyril continued to look after his private patients, however, until shortly before his death at age 82 .

At his funeral, people told me that he had been their GP for the past 30, 40, 50 years. He had looked after five generations of the same family. Continuity of care was natural. There was no GP contract to get in the way of the essential question: why is this patient here? There was no computer screen pinging out instructions on what to say next.

The fittings of his small surgery were clean, modest, and familiar. I can't imagine that a screed of blood tests and scans helped him to answer the existential questions that doctors are often asked about life or death. Medicine was firstly about conversation, and knowing the patients was fundamental. I suspect that this was not only better for patients but also more satisfying for doctors.

But I admired Cyril most for his decades long campaign against corporal punishment in schools. Catholic Ireland in the 1960s held the view that the religious orders charged with teaching in schools should beat and hurt children as a method of discipline. This outraged Cyril. His children were home schooled until he found a (Protestant) school that didn't include violence as part of the curriculum.

He wrote, petitioned, and spoke out about the incompatibility of Christian beliefs with the beating of children. He noted that the only two professions in Ireland delivering corporal punishment as part of their services were prostitutes and Catholic teachers. This didn't go down terribly well in the Catholic hierarchy.

The government eventually intervened, outlawing physical punishment in schools in 1982. The full and horrendous story of physical and sexual abuse in Catholic schools in Ireland is only now being fully told.

Cyril was tolerant, kind, generous, and funny. He was the essence of general practice. I will miss him terribly.

Competing interests: I have read and understood the BMJ policy on declaration of interests and declare the following interests: I'm an NHS GP partner, with income partly dependent on Quality and Outcomes Framework points. I'm a part time undergraduate tutor at the University of Glasgow. I've written two books and earn from broadcast and written freelance journalism. I'm an unpaid patron of Healthwatch. I make a monthly donation to Keep Our NHS Public. I'm a member of Medact. I'm occasionally paid for time, travel, and accommodation to give talks or have locum fees paid to allow me to give talks but never for any drug or public relations company. I was elected to the national council of the Royal College of General Practitioners in 2013 and am chair of its standing group on overdiagnosis. I have invested a small amount of money in a social enterprise, Who Made Your Pants?

Provenance and peer review: Commissioned; not externally peer reviewed.

Follow Margaret on Twitter, @mgtmccartney

Cite this as: BMJ 2015;351:h4582

๑ BMJ Publishing Group Ltd 2015 